\title{
Twin Texts: a Possibility to Involve Children in Inquiry-oriented Processes
}

\author{
Claudia Yolanda Becerra Camargo
}

\begin{abstract}
This article reports on the experience I lived while implementing the instructional design of my Master thesis. The research proposal I am currently carrying out is primarily concerned about conflict resolution and cooperative learning in the English classroom. The proposal was developed in a public primary school in Ciudad Bolivar, Bogotá, Colombia. Besides, my participants were a group of fourth graders. The methodology used during the implementation had to do with: cooperative learning, in which learning implies co-construction. The authoring cycle that is an option for involving students in inquiry processes, and twin texts, understood as the use of two books (one fictional \& one non-fictional) related to the same topic but from different perspectives. The three elements described above were interwoven along the process. To conclude, this experience helped me to recognize certain aspects regarding my professional practices: first, the importance of innovation. Second, the value of other teacher-researchers' experiences and insights. Third, to recognize our students as owners of their learning process. Fourth, how the authoring cycle promoted cooperative learning and decreased conflicts. Finally and foremost, the value of literature as a powerful language learning resource.
\end{abstract}

Key words: inquiry-oriented curriculum, the authoring cycle, twin texts, literacy development, cooperative learning, innovation, conflict resolution.

\section{Resumen}

Este artículo reporta la experiencia que viví mientras implementaba el diseño instruccional de mi tesis de Maestría. La propuesta de investigación que estoy desarrollando actualmente tiene que ver principalmente con resolución de conflicto y aprendizaje cooperativo en la clase de inglés. La propuesta fue desarrollada en una escuela primaria pública en Ciudad Bolívar, Bogotá, Colombia. Además, mis participantes fueron un grupo de niñ@s de cuarto de primaria. La metodología usada durante la implementación tuvo que ver con aprendizaje cooperativo, en el que aprendizaje implica co-construcción. El ciclo de autoría que es una opción para involucrar a los estudiantes en procesos de investigación, y libros gemelos, entendido como el uso de dos libros (uno de ficción y otro de no- ficción) relacionados con el mismo tema pero desde diferentes perspectivas. Los tres elementos descritos antes estuvieron entretejidos a lo largo del proceso. Para concluir, esta experiencia me ayudo a reconocer ciertos aspectos con relación a mis prácticas profesionales: primero, la importancia de la innovación. Segundo, el valor de las experiencias y reflexiones de otr@s profesor@s investigador@s. Tercero, reconocer a nuestros estudiantes como dueños de sus procesos de aprendizaje. Cuarto, como el ciclo de autoría promovió el aprendizaje cooperativo y disminuyo los conflictos. Finalmente y más importante, el valor de la literatura como un recurso poderoso en el aprendizaje de una lengua.

Palabras claves: currículo orientado a la indagación, el ciclo de autoría, libros gemelos, desarrollo de la lectoescritura, aprendizaje cooperativo, innovación, resolución de conflictos.

* Received: 07-02-06 / Accepted: 17-07-006 


\section{Context}

This project is taking place in a public primary school located in Ciudad Bolivar-a heavily depressed quarter of Bogotá-with a group of about forty children whose ages range from nine to twelve years old. This course of fourth graders is one of the most problematic ones in terms of discipline; indeed, the environment and the socio-economical situation of my students and their families are not the most appropriate for children to grow up: one finds dysfunctional families, violence, forced displacement, hunger, poverty, unemployment, maltreatment, and lack of love, to mention some of them. Although students do have a high capacity for resiliency since they are respectful, kind, friendly, funny, and warm hearted with people, I did find after a one-month systematic observation of my classroom settings that my primary students used to have several problems among themselves while working together. Thus, the research proposal I am currently carrying out is primarily concerned about conflict resolution and cooperative learning in the English classroom.

As time has passed by, I have observed very positive changes. I have decided to concentrate on this group because there are still some problems when they interact among themselves. Almost everyday, there are disputes. In their English classes, most of them have shown a high degree of motivation even though they are not as responsible as they should be with the tasks assigned. To conclude, I am collecting data from the entire group of students while they work in cooperative learning activities, by using videotapes and conferences as primary sources, and audiotapes and field notes as secondary sources.

\section{Definition of twin texts}

In broad terms, twin texts share a common topic, but they differ in the way they present it. One of them is an informational text, and the other is a fictional one. Thus, students have the chance to study a topic from a fictional and nonfictional perspective. In words by Camp (2000):

twin texts are two books, one fiction and one non-fiction (informational), on the same (or related) topic (. . .). While the non-fiction book answers questions in a more straightforward manner, the story structure of a fiction book may be less difficult for children to comprehend. Teachers can integrate language arts, science, social studies, and other content areas by using children's literature as a bridge. (p. 400) 
I decided to implement twin texts as part of my thesis' instructional design for the following reasons: First, after implementing for a month several cooperative learning activities I found in theory, I noticed that they were not giving my children stances to cooperate and interact. In short, I realized that I needed to adapt or reshape them in order to boost cooperation in my particular setting. Second, twin texts combine inquiry-oriented processes and literacy development since they give students the chance to wonder and learn about different topics from two perspectives. Finally, I found twin texts that provided more information about the topic children were studying in science; i.e., Colombian ecosystems. The twin texts I could use after a long search were: The Very Hungry Caterpillar, which is a fictional book, and A Monarch Butterfly's Life, that is an informative text. These books were relevant to my students' topic of study since butterflies in Colombia are part of our ecosystems, and our country possesses one of the widest varieties of them around the world.

\section{The Inquiry-oriented Process}

To begin with, inquiry demands changes in learning and teaching practices. For Short (2001), for example, it is a great change of perspective: "inquiry goes beyond building curriculum from students to negotiating curriculum with students" (p. 21). Likewise, Clavijo (2001) reinforces the idea of changing the traditional way of teaching (in which the teacher has the whole control) to engage students in active learning processes. For her, when students and teachers are responsible for the construction of curriculum, the educational process becomes more meaningful and engaging: "it takes for teachers thinking and searching about different ways to teach and a strong believe that their students will learn, and from students an active rather than passive role in classroom activities" (p. 34).

Nevertheless, for Pataray and Roberson (2002) there are certain misconceptions teachers usually have in relation to the inquiry-oriented curriculum. I consider that one the most common in our educational settings is the fear of not being able to "cover" the topics one is supposed to teach. It happens because under this new perspective, one as a teacher cannot control the process since one's students and their inquiries are the ones who determine the route. The boat is under their control and one is she or he who supports, helps, and guides the journey. One as a teacher is like the compass. This new 
perspective matches the approach to learning I am trying to implement at school: i.e., social constructivism. However, it is a long and slow process of change for most teachers and pupils who have been educated until now under traditional paradigms.

\section{The Authoring Cycle}

In their book Creating Classrooms for Authors and Inquirers, Short, Harste, $\mathcal{E}$ Burke, (1996) explain that in what they call "the authoring cycle" (p.261) the knowledge systems (science, social studies) and the sign systems (reading, writing, arts) "become tools for exploring, and researching student questions" (p. 261). I will present each one of the cycle stages as I lived them in my classroom practice in the light of various scholars' and teacher-researchers' experiences in relation to inquiry.

\section{Building From the Known}

This first stage refers to the variety of experiences a teacher can present to his or her students, so that the teacher can "build" the inquiry process upon those experiences. Thus, I planned a series of activities beginning with the reading aloud of the story The Very Hungry Caterpillar to the whole class. Students listened and participated actively to understand the story. Afterwards, I invited them to fill in a K-W-L-N chart -i.e., what I Know, what I Want to know, what I Learnt, and New questions- (See appendix 1) in order for them to write down what they knew about the caterpillars and the butterflies and to jot down the questions they would like to pose regarding these animals. At the beginning, they worked individually; then, I invited them to share their knowledge and questions with a peer, and finally I encouraged them to work in teams of four.

Next time, the class devoted its time to digging once more into their prior knowledge. The activity consisted of giving each team materials for them to prepare and present a poster in which they expressed what they knew about butterflies and caterpillars. They were very engaged in the task and at the end of the session, they presented their work to the class.

\section{Taking the Time to Find Questions for Inquiry}

In fact, my fourth graders went through this second step quite fast and well. I was amazed. I had never thought of the quality of questions my children could 
ask. As in the K-W-L-N chart they had to write down their questions, after the posters presentation, I encouraged each team to sit together, to read each one of their questions and to decide which one of them from the team would like to answer. My pupils posed these questions:

- Where was the butterfly born?

- How was the butterfly born?

- Where do butterflies live?

- How do butterflies make the cocoon?

- Why do butterflies reproduce in a cocoon?

- Why are butterflies caterpillars before becoming butterflies?

- Why do the butterflies have colors in their wings?

- Why are the caterpillars from different colors?

- Why are the butterflies invertebrate?

- Why do the butterflies leave from the caterpillars?

- How is the caterpillar born?

Afterwards, the class made a web on the board pinning up the questions written on cardboard. In addition, each team prepared a cardboard butterfly in which they had to write, on one side, the sources and places in which they could find information related to their queries, and on the other side, the sources they may have at home for searching. It was a fantastic experience as well because I realized that they do know a lot of informational texts and the places where they could find them, too.

\section{Gaining New Perspectives}

Currently, we are involved in this stage of inquiry. We have devoted several classes to develop certain skills when searching for information. To begin with, we devoted one class matching the questions they asked in Spanish with their corresponding pairs in English. They used the English dictionary and I gave them some ideas to help them to do their job faster. Later on, I read aloud the second book: A Monarch Butterfly's Life. Before reading the book, I encouraged students to think of their questions, and to check if the book may help them 
to answer their queries. To conclude the session, I brought to class a good amount of books and copies related to butterflies for them to read, look for and go through their inquiry process. I did so because I am aware of the fact that most of them do not have books at home. While searching the materials, I gave them some guidelines about the index and the table of contents, so that they may have a more successful search. I took these two features of informational texts from the book Exploring Informational Texts. From theory to Practice, by Hoyt, Mooney, \& Parkes (2003).

The following session, they had to bring as much material as they may possess for giving answer to their questions. I found out different things: a chocolate bar album, photocopies, Encarta information, English dictionaries, information they wrote down after going to the library, and even a boys' team decided to buy an encyclopaedia together. In short, they brought to class different informational texts. Once again, I was amazed and pleased. I had never seen them so interested about the class before. Also, I brought my material to class again, so that they could continue searching and jotting down ideas. At this time, I explained them a useful graphic organizer (Hoyt et. al., 2003) presented in their book when one is trying to give answer to questions that account for cause-effects. Then, they designed their own graphic organizers to collect information. During all these processes, I was close to help and support them.

\section{Attending to Difference}

Even though my students do not have learning logs like Short et. al. (1996) present in their cycle, I designed a chart they filled in at the end of each lesson (See appendix 2). In this chart, they expressed their feelings in relation to what they liked, what they disliked, the way each one felt and behaved during the class, and how they perceived their classmates' work. In short, it involved self-assessment, peer-assessment, and class assessment. This information was quite helpful because while reading their assessment formats, I discovered things they prefer to do and I confirmed behaviours I noticed when they were working in teams.

The second element Short et. al. (1996) mention in the cycle has to do with revision on inquiry. I have illustrated above the way my pupils have been finding their own paths with my support, but I still need to stress the fact 
that the course has created a cooperative atmosphere. As a result, whenever someone finds information in relation to a team question, they inform me and they share it with their classmates.

To conclude, the two stages of the authoring cycle that are to be implemented next refer to the presentation of each team answers, in which the idea is that every team decides upon the sign system they may want to use to share their process. Then, the idea is to continue searching and inquiring. At this point, the K-W-L-N chart will be used again, but filling in the last column of it. Finally, the stage of taking thoughtful new action refers to the more informed, reflective, and conscious inquiry cycle my students and I will be living, hopefully for a long time.

\section{Conclusions and Pedagogical Implications}

To begin with, this experience has taught me a lot in regards to the following aspects: first, I have reflected upon the importance of innovation in our teaching practices. Innovation implies, from my point of view, recognizing our role as agents of change. Also, I have realized that at times what is stated in theory does not provide us with the elements we need for the every day situations we usually live as educators. That is why, readapting or reshaping certain elements stated in theory is needed. In my particular case, I took advantage of this fact, I learnt and changed the way of approaching my classes. I consider that this is part of becoming a teacher-researcher.

Second, in the innovative process I have been living, I had two main sources of information which I think may illuminate teachers' practices. On the one hand, the insights and understandings of other teacher-researchers: by reading research studies one as teacher can get lots of ideas, and those ideas may make a big difference. And, on the other hand, a change of perspective as well as the manner to recognize our students' voices in the classroom imply giving students the opportunity to become owners of their learning process.

Third, I have noticed how the conflicts that emerged among my students decreased while they were inquiring about the questions they posed. Additionally, the inquiry-oriented practice I implemented as part of the instructional design of my thesis project promoted cooperative learning since each team member was interested in contributing to giving an answer to the team's question. In 
fact, this methodological experience has really enriched my teaching practice and my students' learning process, too.

Finally and foremost, implementing literature in the teaching of English and as the launching activity of an inquiry-oriented cycle is a powerful resource. Bearing in mind Halliday's statements regarding the nature of language, I would suggest educators to take into consideration inquiry-oriented practices as means of learning language, learning through language, and learning about language (Halliday, 1979, as cited by Clavijo, 2001). In my particular case, my students learnt language while they were exposed to twin texts. They learnt through language due to the fact that they were looking for information in a diverse amount of sources. And they are learning about language, specifically the English language, because they are in the process of expressing their ideas and understandings in regards to the research questions they posed in English.

\section{References}

Camp, D. (2000). It takes two: teaching with twin texts of fact and fiction. The Reading Teacher, (53), 5, 400-408.

Clavijo, A. (2001). Redefining the role of language in the curriculum: inquiry-based curriculum an alternative. Colombian Applied Linguistics Journal,(3), 1, 32-48.

Hoyt, L., Mooney M., \& Parkes, B. (2003). Exploring Informational Texts. From Theory to Practice. Portsmouth: Heinemann.

Pataray- Ching, J., \& Roberson, M. (2002). Misconceptions about a curriculum-as-inquiry framework. Language Arts (79), 6, 498-505.

Short, K., Harste, J., \& Burke, C. (1996). The authoring cycle as curricular framework for inquiry. In: Creating Classrooms for Authors and Inquirers. Portsmouth: Heinemann.

Short, K. (2001). Curriculum as inquiry: inquiring into inquiry by examining our beliefs and practices. Colombian Applied Linguistics Journal (3), 1, 21-31. 


\section{Appendix 1}

K-W-L-N Chart

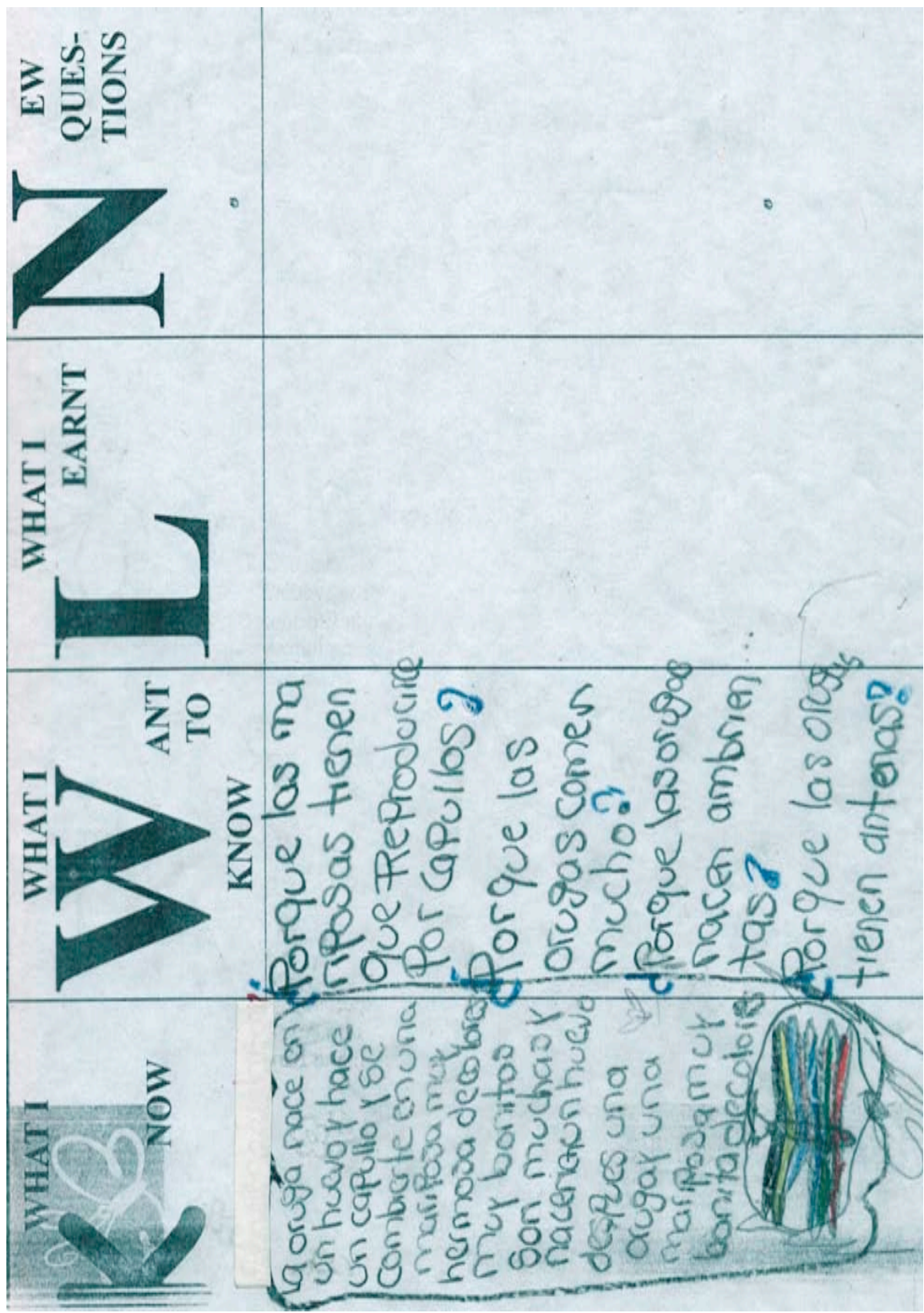


APPENDIX 2:

Assessment Chart

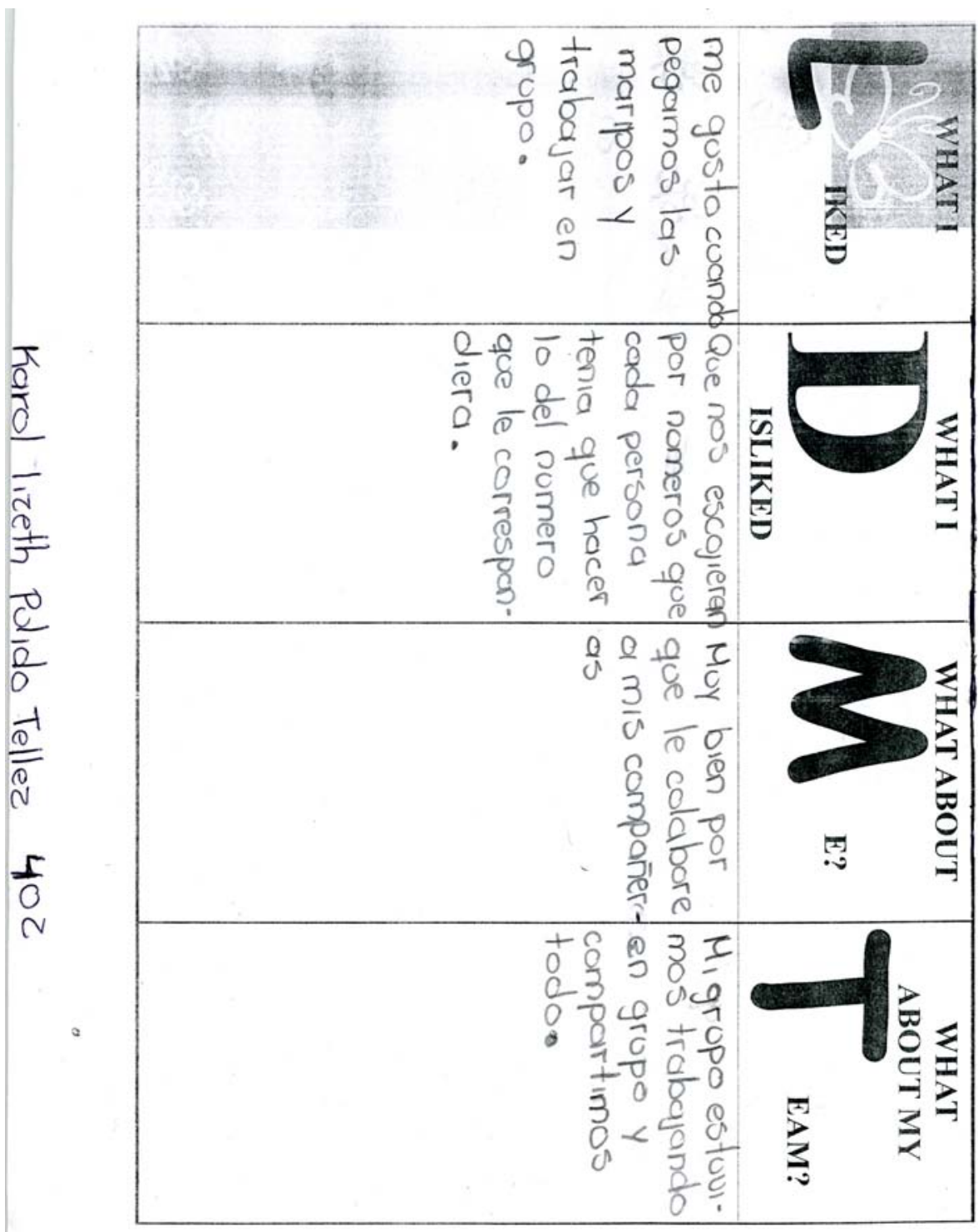




\section{THE AUTHOR}

Claudia Becerra holds a B.A. in Modern Languages from Universidad Distrital and she is a candidate to the Masters in Applied Linguistics at Universidad Distrital. She has been a teacher for the Secretary of Education in Bogotá since 2000. She is working at Institución Educativa Distrital IED Naciones Unidas II, Ciudad Bolívar, Bogotá, and as a tutor of the PROFILE teacher development programme. 